\title{
State Theory
}

\section{Putting the Capitalist State in its Place}

Bob Jessop

State Theory offers a comprehensive review of the existing literature on the state and sets a new agenda for state research.

"This book makes a very substantial contribution to the literature on the state. It constitutes a magisterial tour through the development of state theory in the 1970s and 1980s, engaging virtually every significant current of theoretical work on the state in the period (from a number of different national literatures, not just Anglo-American): Marxist structuralism, German state-derivation approaches, the French regulation school, discourse theories, statist analyses. What is particularly striking about the book is that Jessop so systematically pursues a positive, theoretical project of his own; the text is thus not a series of endless, tedious synoptic reviews, but an energetic critical engagement with other work for purposes of establishing the central elements of his own, developing, perspective."-Erik Olin Wright, University of Wisconsin, Madison

In State Theory Bob Jessop, one of Europe's leading Marxist theorists in Europe and the United States, has developed a novel approach to state theory. Four central themes define the scope of the book: an account of the bases of the operational autonomy of the state; the need to develop state theory as part of a more general social theory; the possibilities of explaining "capitalist societalization" without assuming that the economy is the ultimate determinant of societal dynamics; and a defense of the method of articulation in theory construction.

Bob Jessop is Professor of Sociology at the University of Lancaster and author of The Capitalist State (Martin Robertson, 1982), Nicos Poulantzas (St. Martin's Press, 1985), and Regulation Theory and the Transition to Post-Fordism (Polity Press, 1990).

380 pages $6 \times 9$ cloth: $\$ 45.00$ paper: $\$ 14.95$ January ISBN 0-271-00735-4 (cloth) ISBN 0-271-00745-1 (paper)

For sale in the United States and Canada only

\section{PENN STATE PRESS}

Suite C, 820 North University Drive, University Park, PA 16802 (814) 865-1327 


\section{Federal Social Policy}

\section{The Historical Dimension}

\section{Donald T. Critchlow and Ellis W. Hawley, Editors}

Reflecting the growing interest in social policy history, this book provides a penetrating examination of the development of social policy in 20thcentury America. An introductory chapter serving as an overview to the field is followed by seven original essays which explore the historical context for understanding the formulation, implementation, and administration of social policy.

Robert Kelley's foreword discusses the growth of policy history in recent years. In his introduction Donald Critchlow argues that "policy history" encompasses historical reconstructions of development in particular social policy areas and attempts to make overall sense of policy-making processes. The chapters are presented in two sections. The first, Reconstructions of Policy Developments, includes W. Andrew Achenbaum's account of federal policies toward the aged since 1920; Brian Balogh's discussion of the emergence of the Social Security Board as a political actor, from 1935 to 1939; and Judith Sealander's examination of policy formation and women's issues between 1940 and 1980. In the second section, The Historical and Institutional Contexts of Policy-making, Morton Keller addresses social policy in 19th-century America; Ellis Hawley writes on social policy and the liberal state in 20thcentury America; Jack L. Walker examines interests, political parties, and policy formation in the American democracy; and Edward Berkowitz concludes with an essay on social welfare and the American state.
With studies representative of the best work in the historical analysis of social policy, this volume will be of interest to scholars in history, political science, and public policy, as well as to educated laymen seeking to understand social policy as it has emerged in modern America.

Donald T. Critchlow earned his Ph.D. from the University of California at Berkeley and is professor of history at the University of Notre Dame. He has authored or edited numerous works, including The Brookings Institution, 1916-1952: Expertise and the Public Interest in a Democratic Society. Ellis W. Hawley, professor of history at the University of Iowa, earned his Ph.D. at the University of Wisconsin. His published works include The New Deal and the Problem of Monopoly and The Great War and the Search for a Modern Order.

\section{$192 \mathrm{pp} .1 \mathrm{ill}$. \\ LC 87-19395 ISBN 0-271-00617-X \\ $\$ 22.50$}

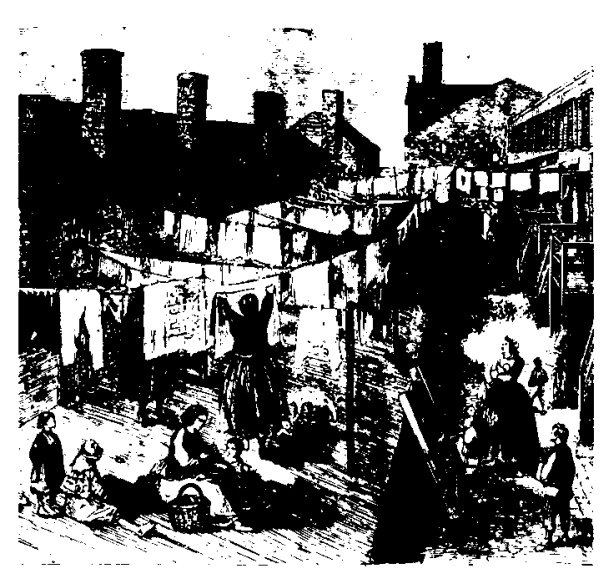

PENN STATE PRESS Suite C 820 North University Drive University Park, PA 16802 (814) 865-1327 


\section{The Central Intelligence Agency}

\section{An Instrument of Government, to 1950}

\section{Arthur B. Darling \\ With Introduction and Annotation by \\ Bruce D. Berkowitz and Allan E. \\ Goodman}

"The State Department, the Federal Bureau of Investigation and the military hampered the Central Intelligence Agency in its infancy by bickering about authority, according to a long-secret history of the agency's early years. The 1,000-page narrative, written in 1953 by the agency's first historian, Arthur B. Darling, is the first CIA document to be declassified and transferred to the National Archives for release to the public under the agency's historical review program.'

- New York Times, November 28, 1989

This unique history offers the most detailed and best documented account of the early years of the CIA currently available. It reveals the political and bureaucratic struggles that accompanied the creation of the modern U.S. intelligence community. In addition, it proposes a theory of effective intelligence organization, applied both to the movement to create the CIA and to the form it eventually took.

The period covered by this study was crucially important because it was during this time that the main battles over the establishment, responsibilities, and turf of the agency were fought. Many of these disputes framed the issues that were to be the focus of continuing controversy over the following forty years, such as the relationship of the CIA to other government agency intelligence operations, the role of covert action, and
Congressional oversight of the intelligence community.

Besides the historical narrative, Darling's study makes two important theoretical arguments. First is that effective intelligence is the product of organizations rather than individuals; centralizing the collection and dissemination of information and coordination of estimates both improve the effectiveness of intelligence. Second is that the intelligence community should be an "Instrument of Government," meaning (by "instrument") that intelligence should be a tool, separate from the policymaking process, and (by "government") that intelligence should not be produced by a single agency but by the government as a whole.

The sources upon which Darling drew for this study include the files of the National Security Council, the wartime files of the OSS, and interviews and correspondence with many of the principal players, some of whom were given the opportunity to add brief notes of their own elaborating, explaining, or contradicting Darling's account.

Arthur B. Darling taught at Yale University. He served as historian for the CIA from 1952 to 1954 . Bruce D. Berkowitz is Associate Lecturer in Political Science at George Washington University. Allan E. Goodman is Associate Dean of the School of Foreign Service and Professor of International Affairs at Georgetown University. Berkowitz and Goodman are co-authors of Strategic Intelligence for American National Security (Princeton, 1989). Both formerly held positions at the CIA, and Berkowitz also served as a staffer for the Senate Intelligence Committee.

\section{2 pages $6 \times 9^{\prime \prime}$ October}

ISBN 0-271-00715-X Cloth: $\$ \mathbf{6 0 . 0 0}$

ISBN 0-271-00717-6 Paper: \$17.50T

\section{PENN STATE PRESS}




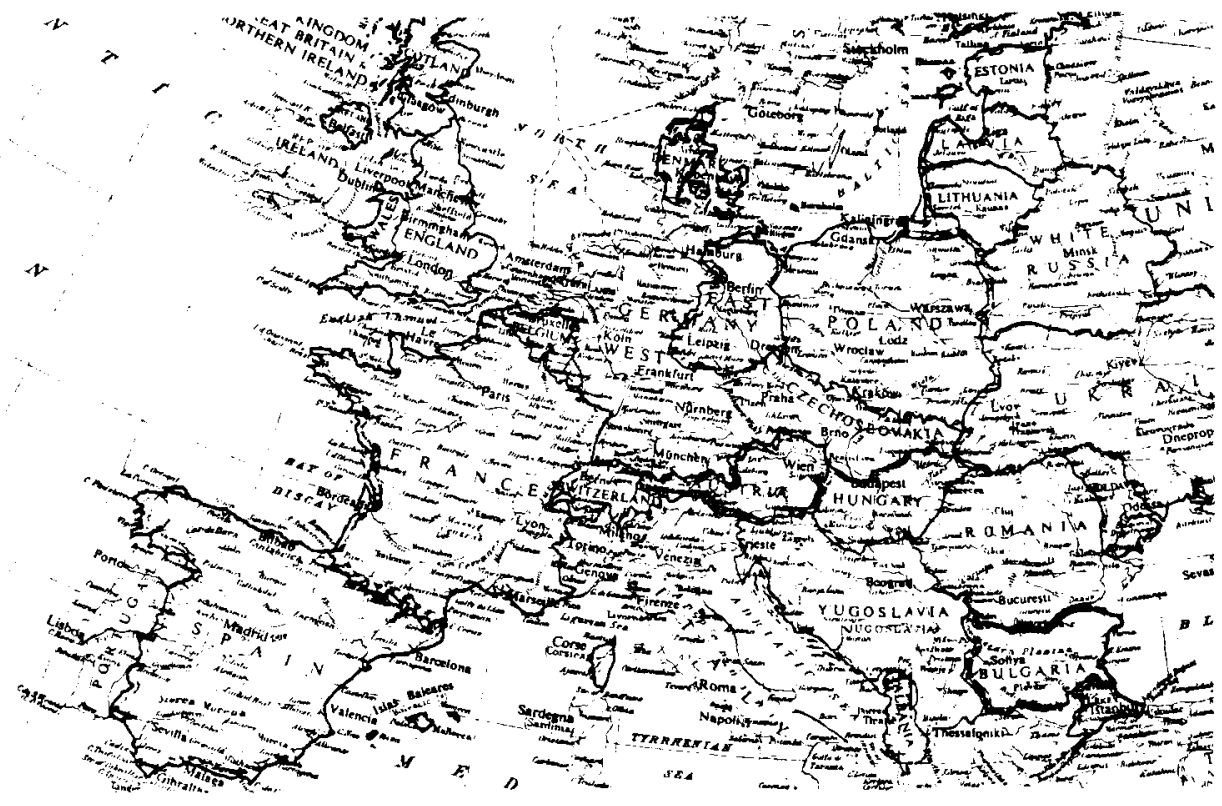

\section{State Failure}

\section{The Impotence of Politics in Industrial Society}

\section{Martin Jänicke \\ Translated by Alan Braley}

"State Failure is provocative, wellargued, and likely to make a big impact on debates in the areas of theories of the state, comparative political economy, innovation, alternative politics, and environmental policy. At a time when Americans are realizing that simply deregulating everything may produce a large amount of dysfunction, State Failure offers a welcome corrective to the lack of discourse in this area."

- Christopher S. Allen, University of Georgia

In an age when areas such as health, education, and the environment are becoming more and more dependent on the state, the state demonstrates again and again that it is not able to cope. State Failure is about this failure of states in both the East and the West to make urgent economic and political decisions. The problem, Jänicke argues, begins in the political sphere where politicians, who are elected to make decisions, become merely the legitimators of their government departments.

The roots of the problem lie deeply embedded in the industrial structure, a structure that has passed its innovative phase and relies increasingly on public resources. Examining the failure of states in both Eastern and Western Europe, Jänicke concludes that we face a future of either stagnation or stark deindustrialization unless political means are found to solve the problems - from environmental destruction to unemployment - that now face us all.

Martin Jänicke is Professor of Comparative Political Science at the Free University, Berlin.

200 pages $6 \times 9^{\prime \prime} \quad \$ 29.95$ September ISBN 0-271-00714-1

For sale only in the United States and Canada

\section{PENN STATE PRESS}

Suite C, 820 North University Drive, University Park, PA 16802 (814) 865-1327 


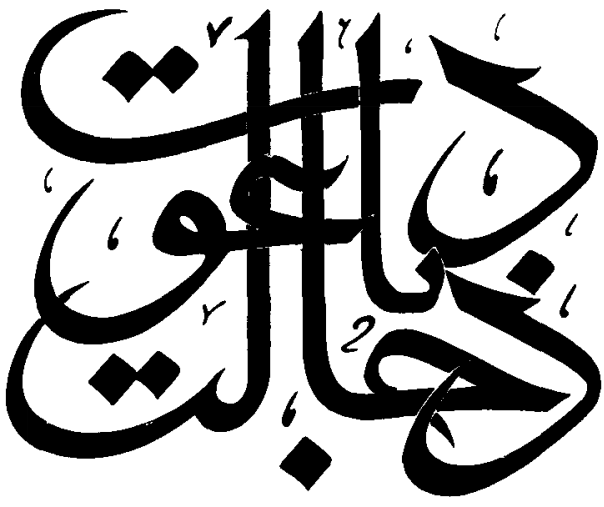

Involvement by Invitation

American Strategies of

Containment in Iran

\section{Kuross A. Samii}

This book is a perceptive analysis of the historical events that led to America's untidy encounter with the Iranian revolution. Based on extensive archival research and written in an engaging and forthright manner, it examines American-Iranian relations against the backdrop of American-Soviet rivalry.

Because the diplomatic record beyond the 1950s is not yet available to scholars, the author focuses his inquiry on the critical period preceding the oil agreement of 1954. Special attention is given to the Azerbaijan crisis of 1946 and the overthrow of Musaddiq in 1953. These events are depicted as being central to the study of American-Iranian relations, and are analyzed as examples of different methods and approaches of America's strategy of containment.

In surveying American-Iranian diplomatic history, the author shows that following the establishment of formal ties between the two countries in 1883, the efforts of Persian monarchs to invite American involvement in their country had the genuine support of the people in Iran. But after the oil agreement of 1954, the benevolent image of America in that country began to change. The eventual result was a vast disparity between the pro-American stand of the Shah's government and the sentiments of the Iranian people.

Throughout this study, the author is concerned with the efficacy of American policies and their relevance to the subsequent American experience in Iran. In a broader frame, he examines the style and modalities of U.S. foreign policy toward the Third World in general, and the substance and process of covert operation as an instrument of U.S. policy. The conclusions of Involvement by Invitation call for an unambiguous vision of American policies and an awareness that America's interests are threatened as much, if not more, by the appalling social and economic inequities of the Third World as they are by the Communist penetration of these countries.

Kuross A. Samii is a Washington-based writer and Middle East specialist. He received his $\mathrm{Ph} . \mathrm{D}$. from the School of Advanced International Studies, The Johns Hopkins University, and has worked as Research Associate at the Woodrow Wilson International Center for Scholars and as Research Fellow for the United States Senate.

$208 \mathrm{pp} .10$ ill.

LC 86-43035 ISBN 0-271-00490-8

$\$ 24.95$

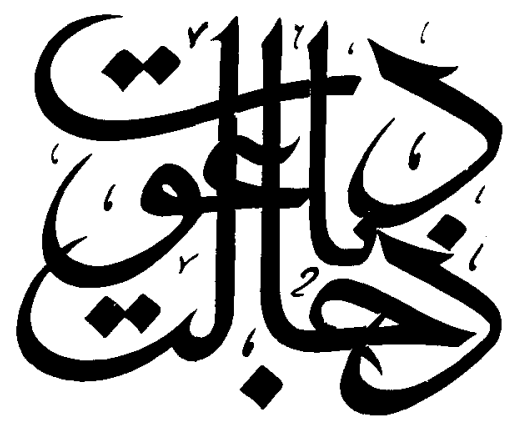




\section{Intervention and}

\section{Underdevelopment: Greece During the Cold War}

\section{Jon $V$. Kofas}

“. . this ground-breaking study by Jon Kofas ... provides an insightful analysis of the American aid program that determined the political and economic configuration of postwar Greece. Kofas's analysis, however, is equally significant for United States history because it was on Greek soil that American counterinsurgency, pacification, and containment tactics were evolved, tested, and later applied elsewhere in the Third World.

Those who seek meaningful reappraisal rather than beguiling rationalization might well begin with this study, solidly grounded on all available sources. It presents a revisionist perspective regarding both the economic and the political development of Greece under American tutelage. The declared objective of the economic aid was to avoid restructuring of the Greek economy, and to preserve Greece as an exporter of raw materials and an importer of manufactured goods. Kofas asserts that an alternative program similar to that of the northern Balkan countries was feasible, and that failure to undertake such a program is responsible for the dependence and vulnerability of today's Greek economy.

Likewise in the political realm, Kofas rejects the Washington dogma that Greece has to be in either the Soviet or the American camp, and therefore must be in the latter. Kofas proposes as a 'plausible alternative' a socialdemocratic regime that, in addition to socioeconomic reforms at home, could have pursued abroad a pro-Greek rather than a pro-Soviet or pro-American course.
The victory of the Americansupported forces in Greece obscured this alternative vision for decades. Yet it was persistently propounded, in the face of discouraging odds, by a variety of centrist and leftist leaders. With the coming to office of Andreas

Papandreou, this vision has become official policy in Athens. Furthermore, assorted versions of this alternative strategy are cropping up globally, which is the underlying reason why the Third World today is out of control. And also why superpower doctrines and projects not recognizing this indisputable and irreversible fact are experiencing difficulties as embarrassing as they are predictable. Hence the broad significance of this thoughtful and thought-provoking study." From the Foreword, by L. S. Stavrianos

Jon V. Kofas, author of Authoritarianism in Greece, teaches history at Marquette University.

\section{$230 \mathrm{pp}$.}

LC 88-26572 ISBN 0-271-00661-7

$\$ 24.95$ April 1989

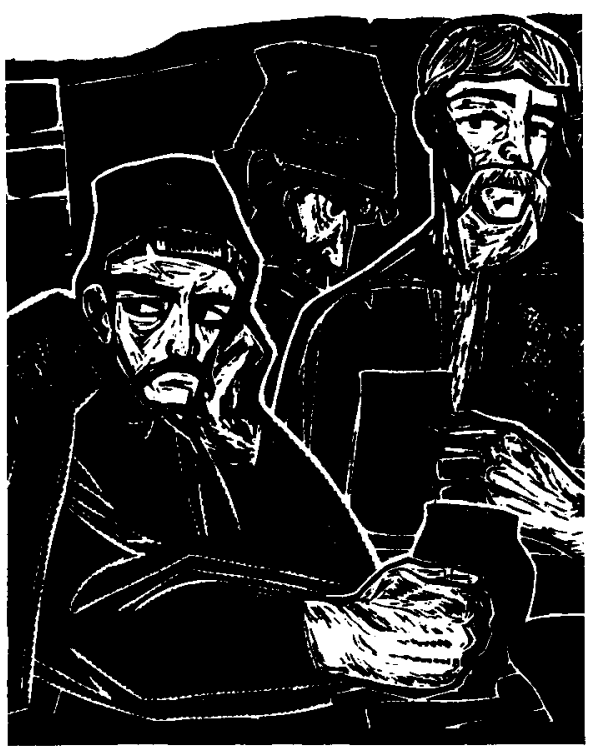

